\title{
Jaguar Landover: A Traditional English Car Manufacturer in Indian Hands - A Good Deal? An Evaluation
}

Fiedler FFH-J*

Department of Economics, TU Dresden, Germany

\begin{abstract}
In 2013 Jaguar Land Rover has been bought by Indian car manufacturer, Tata Motors Ltd. Since then, many suspicious eyes lay on JLR. This evaluation is meant to analyse, whether being bought by Tata was good or bad for Jaguar Land Rover as a traditional British company. For this, a brief introduction of the company is given. Then cost behavior will be analysed. After, JLR's budgeting process will be reviewed. In order to gain insight to the financial metrics a firm's performance analysis will be conducted and capital spending will be viewed. Last, a competitive analysis will be done and a balanced scorecard sketch will be given. Adding all of these particular analyses to an overall puzzle will give (especially comparing these findings with market and competition) a reliable answer where Jaguar Land Rover is standing today and if the take-over through Tata in rough times was the right measure for both sides.
\end{abstract}

Keywords: Market; Business; Cost; Capital; Financial; Investment; Customer satisfaction; Budgeting; Accounting; Manufacturing

\section{Brief Description of the Company}

\section{Industry segments}

According to their Website, Jaguar Land Rover is UK's biggest car manufacturer producing "one of the world's premier luxury sports saloons and sports car marques" [1]. Primarily Jaguar offers sports vehicles and limousines, having newly introduced the Jaguar F Pace, a premium SUV, chasing the tail of famous Porsche Cayenne [2].

\section{Geographic service area}

In 2015 Jaguar Land Rover sold 487.065 vehicles in 160 countries [3]. According to Jaguars Website the biggest three markets in 2015 were:

1.) China

2.) Europe

3.) United Kingdom (Figure 1).

Illustration 1: Looking at the illustration above, one could notice

Jaguar Land Rover: global sales 2013-2015, by region 2015 , by region/country (in 1,000 units)

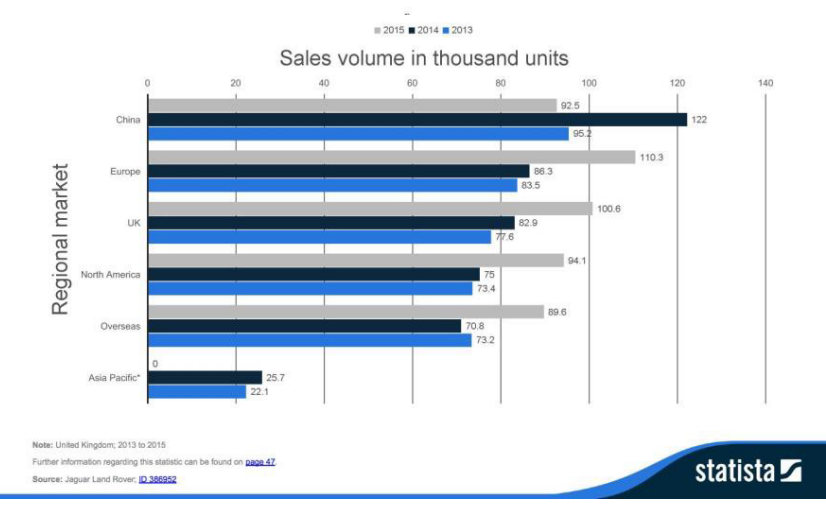

Figure 1: Geographic service area. that in the biggest market, China, there was a huge increase in car sales in 2014 to over one hundred-twenty-thousand vehicles from ninety five thousand vehicles in 2013. In 2015 the car sales dropped again to the level of 2013. As sales where initially surging and in the second period they were shrinking, the average growth was $2 \%$.

In the second biggest market, Europe (excluding Jaguars home market UK) there was a different trend. Here, sales were constantly rising from 2013 onwards. From originally eighty-three-thousand vehicles in 2013, to eighty-six-thousand vehicles in 2014 to finally (with a big jump) hundred-ten-thousand vehicles in 2015. The trend indicates that Europe might soon become Jaguars most important market. The overall rate of growth from 2014-2016 was 32.1\%.

In Jaguar's third-biggest market, the UK, one can observe constantly rising car sales from 2014-2016. From seventy-seven thousand cars sold in 2013, sales rose to almost eighty-three-thousand cars in 2014 to finally reach an amount of one-hundred-thousand cars sold in 2015. This equals an overall rise of car sales by $29.5 \%$ from 2014-2016.

As the Chinese market seems to be very volatile, whereas UK's and Europe's market where constantly roaring the figures suggest that China is losing its predominant role for car manufacturer Jaguar Land Rover in the next years.

\section{Market position}

Jaguar Land Rover is Britain's largest car manufacturer, having it's headquarter in the East Midlands, in Coventry (Figure 2) [3]. Also Joint Company Jaguar Land Rover Ltd. Spent 12 bn. GBP in R \& D, therefore being the largest R \& D investor in UK's manufacturing sector (ibid).

${ }^{*}$ Corresponding author: Frederic Florian Hans-Joachim Fiedler, Department of Economics, TU Dresden, Wittenberger Str. 64, Dresden, Saxony 01309, Germany, Tel: +4917624700201; E-mail: frederic.fiedler@mailbox.tu-dresden.de

Received July 20, 2018; Accepted August 27, 2018; Published August 31, 2018

Citation: Fiedler FFH-J (2018) Jaguar Landover: A Traditional English Car Manufacturer in Indian Hands - A Good Deal? An Evaluation. J Account Mark 7 : 292. doi: 10.4172/2168-9601.1000292

Copyright: ( 2018 Fiedler FFH-J. This is an open-access article distributed under the terms of the Creative Commons Attribution License, which permits unrestricted use, distribution, and reproduction in any medium, provided the original author and source are credited. 
Citation: Fiedler FFH-J (2018) Jaguar Landover: A Traditional English Car Manufacturer in Indian Hands - A Good Deal? An Evaluation. J Account Mark 7: 292. doi: 10.4172/2168-9601.1000292

Page 2 of 7

On the Chinese market (Jaguars biggest market) in the first half of 2014, Jaguar Land Rover (short: JLR) ranked fourth place behind German car manufacturer Audi, BMW and Mercedes-Benz, selling sixty-thousand cars [4].

Illustration 2: In Europe, including UK, in 2016 until August JLR has sold one-hundred-forty-three cars, having a market share in 2016 of 7.8\% [5]. Europe has relegated China from the first place, concerning sales-growth and importance. In China, JLR just accounted for $12.5 \%$ of the car sales in 2016 (ibid).

\section{Illustration 3: a) Size measured by revenue}

In 2011 JLR had revenue of 9,871 bn. GBP [6]. Sales revenues where constantly rising to 22,208 bn. GBP in 2016 (Figures 3 and 4).

\begin{tabular}{|c|c|c|}
\hline China & $\begin{array}{c}\text { Volume Sales Through } \\
\text { August }\end{array}$ & $\begin{array}{l}\text { Y-O-Y Volume } \\
\text { Growth }\end{array}$ \\
\hline Audi & 385,734 & $6.8 \%$ \\
\hline BMW & 329,972 & $9.4 \%$ \\
\hline Mercedes-Benz & 292,072 & $31.9 \%$ \\
\hline Jaguar Land Rover & 71,659 & $24.9 \%$ \\
\hline Total Passenger Vehicle Market & & $12.5 \%$ \\
\hline United States & $\begin{array}{c}\text { Volume Sales Through } \\
\text { August }\end{array}$ & $\begin{array}{l}\text { Y-O-Y Volume } \\
\text { Growth }\end{array}$ \\
\hline Mercedes-Benz & 241,890 & $1.3 \%$ \\
\hline BMW & 204,744 & $-8.3 \%$ \\
\hline Audi & 134,562 & $3.5 \%$ \\
\hline Jaguar Land Rover & 66,441 & $25.9 \%$ \\
\hline Total Passenger Vehicle Market & & $0.6 \%$ \\
\hline Europe* & $\begin{array}{c}\text { Volume Sales Through } \\
\text { August }\end{array}$ & $\begin{array}{l}\text { Y-O-Y Volume } \\
\text { Growth }\end{array}$ \\
\hline Audi & 556,765 & $8.0 \%$ \\
\hline Mercedes-Benz & 544,602 & $14.2 \%$ \\
\hline BMW & 531,841 & $11.7 \%$ \\
\hline Jaguar Land Rover & 142,991 & $29.4 \%$ \\
\hline Total Passenger Vehicle Market & & $7.8 \%$ \\
\hline
\end{tabular}

*EU+EFTA countries

Figure 2: Market position

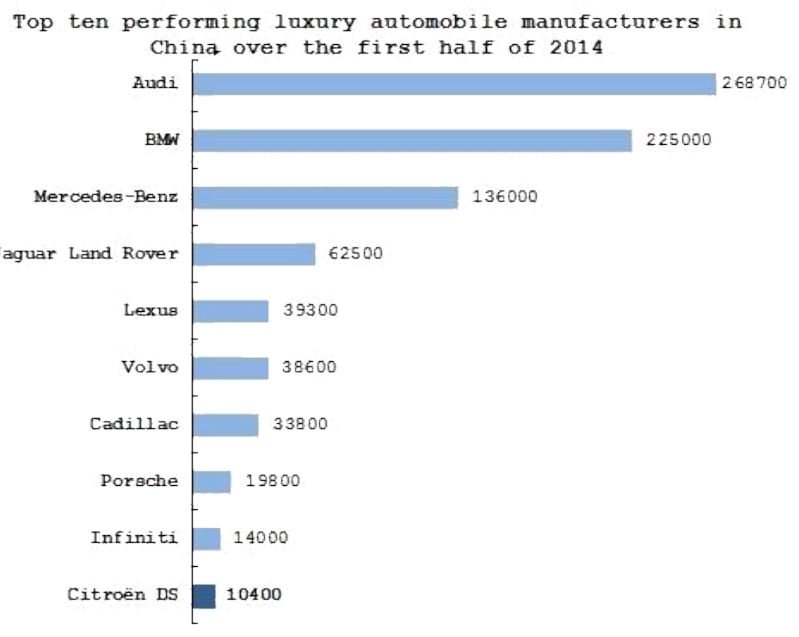

Figure 3: Size measured by revenue.

\section{b) Annual growth rates were (ibid)}

2011/12: $36.89 \%$

2012/13: $16.81 \%$

2013/14: $22.69 \%$

2014/15: $12.90 \%$

\section{Illustration 4:}

Employees: According to the company Website JLR employs thirty-eight-thousand employees directly and further two-hundredseventy-five-thousand employees are associated with the company through dealers and business partners (ibid).

Market capitalization: In the FY2014 JLR possessed total assets of $15,589 \mathrm{bn}$. GBP and total equity of $5,864 \mathrm{bn}$. GBP. Ursa [7] states, that JLR (100\% owned by Tata Motors Ltd.) approximately accounts for $90 \%$ of Tata Motor's share value [7]. According to Yahoo Finance the current market capitalization of Tata Motors Ltd. Is $26.28 \mathrm{bn}$. USD, which equals $18.25 \mathrm{bn}$. GBP [8]. If we take the assumed part of JLR in Tata's market cap of $90 \%$, JLR comprises a current value of $16.43 \mathrm{bn}$. GBP.

\section{Mission Statement and Strategic Objectives}

On the Website of Jaguar Land Rover, the mission statement is predominantly set: 'At Jaguar Land Rover we are driven by a desire to create class-leading products that deliver great customer experiences" [3]. Another remarkable fact is that Tata is re-investing most of JLR's operating cash flow [7]. In 20142.7 bn GBP of the 3 bn. GBP in Operating Cash Flow where re-invested (ibid). One major goal is to strengthen R \& D to get a competitive advantage through technological advancement.

\section{Cost Behavior Analysis of the Business}

\section{Behavior of expenses of the business}

Raw materials account for forty-seven percent of the vehicle production costs [9]. Approximately twenty-two percent of the automaker's operational costs depend on steel (ibid). From 2008-2013 the steel price went down from 15.2 Euros per metric ton to $4.8 €$ per metric ton. This equals a decrease of $68.43 \%$. Mainly because of this decrease of the steel price manufacturers gross margins rose steeply.

On the other side, due to constantly tightening regulations for vehicle emissions and a high innovative pressure on the market's costs for R \& D are perspicuously rising (Figure 5).

Jaguar Land Rover: globol seles revenue 2011-2016

Annual global sales revenue of the British brand Jaguar Land Rover from FY 2011 to FY 2016 (in 1,000,000 GBP)

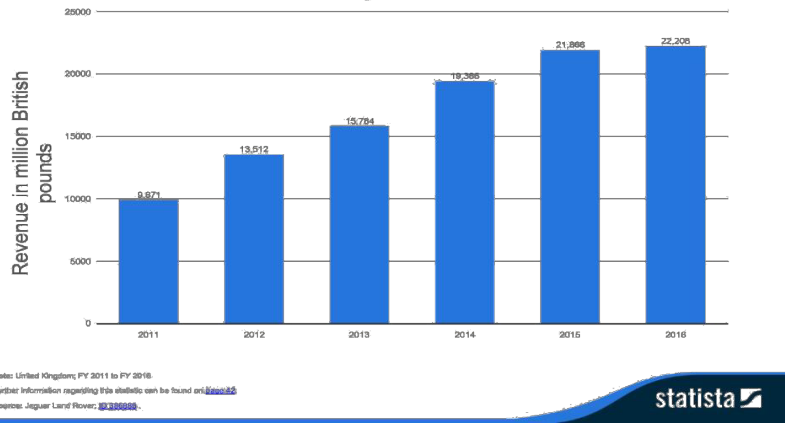

Figure 4: Annual globe sales revenue. 
Citation: Fiedler FFH-J (2018) Jaguar Landover: A Traditional English Car Manufacturer in Indian Hands - A Good Deal? An Evaluation. J Account Mark 7: 292. doi: 10.4172/2168-9601.1000292

Page 3 of 7

\section{Fixed and variable costs}

Analyzing the Income Statements of JLR, we see total fixed costs rising by $44 \%$ from 2013-2015, from originally 3.5 bn. GBP in 2013 to $5.2 \mathrm{bn}$. GBP in 2015. More representative are the fixed costs/Units. Fixes costs per unit rose by $27 \%$ from $8.290,47$ GBP per vehicle sold in 2013 to 10.724,44 GBP per vehicle sold in 2015 (Table 1).

Total variable costs also show an overall increase of $31 \%$ from 2013 2015, originally being $11.4 \mathrm{bn}$. GBP in 2013 ending up to be $15.2 \mathrm{bn}$. GBP. Variable costs per unit are showing an overall increase of $15 \%$. In 2013 the variable cost per vehicle was $26.920,80$ GBP and in 2015 variable cost per vehicle was $31.288,43$ GBP. This means that in 2015 the variable cost per unit were almost 5.000 GBP higher than in 2013.

Illustration 5: The rise of fixed and variable cannot be deducted to the rise of the Produce Price Index, because from 2014-2015 PPI went down by 3.1 points, whereas fixed and variable costs rose significantly.

\section{Relationships between sales volume, costs, and profit}

In 2014 we can see an increase of sales volume by $16 \%$, a rise of costs by $23 \%$ and a huge increase of pre-tax profit by $49 \%$ (Table 2 ). So in 2014 there was an over-proportional influx in profit. In 2015 sales volume slowed down, increase was just $6 \%$. Costs went up by $12 \%$, this

Luxury vehicles: United States premium vehicle market share 2015

U.S. luxury car market share in $\mathbf{2 0 1 5}$, by brand

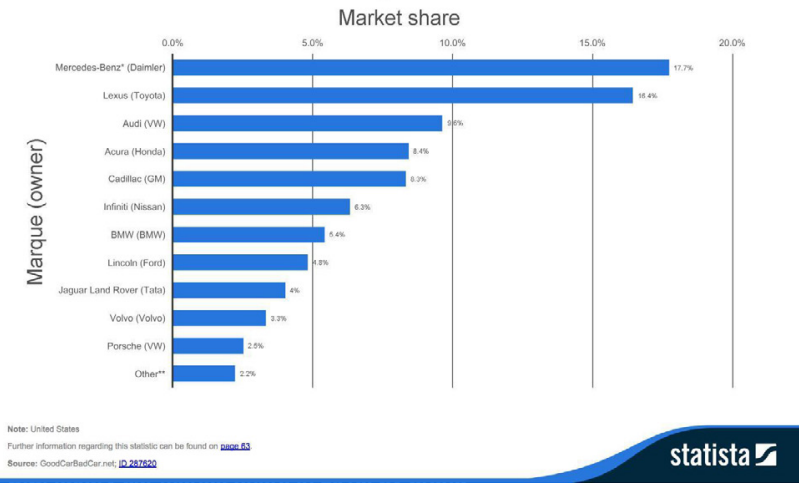

Figure 5: Cost behaviour analysis of business.

\begin{tabular}{|c|c|c|c|}
\hline & 2015 & 2014 & 2013 \\
\hline Units sold & 487065 & 462678 & 425006 \\
\hline $\begin{array}{l}\text { Fixed cost in GBP } \\
\text { (total) }\end{array}$ & 5223500000,00 & 4580000000,00 & 3523500000,00 \\
\hline Inc/Dec. In \% (total) & $14 \%$ & $30 \%$ & \\
\hline Fixed cost/Units & 10724,44 & 9898,89 & 8290,47 \\
\hline Inc./Dec. In \% (per unit) & $8 \%$ & $19 \%$ & \\
\hline Variable cost in GBP & 15239500000 & 13762500000 & 11441500000 \\
\hline Inc./Dec. In \% (total) & $11 \%$ & $20 \%$ & \\
\hline $\begin{array}{c}\text { Variable cost/Units in } \\
\text { GBP }\end{array}$ & 31288,43173 & 29745,30883 & 26920,79641 \\
\hline Inc./Dec. In \% (per unit) & $5 \%$ & $10 \%$ & \\
\hline $\begin{array}{c}\text { Fixed + Variable Costs } \\
\text { in GBP }\end{array}$ & 20463000000,00 & 18342500000,00 & 14965000000,00 \\
\hline $\begin{array}{c}\text { Fixed + Variable Costs/ } \\
\text { Units in GBP }\end{array}$ & 42012,87 & 39644,20 & 35211,27 \\
\hline
\end{tabular}

Table 1: Fixed and variable costs. could be caused by the stiffness of the cost side, not reacting to sales decrease that quickly. In 2015 we can also see an under-proportional increase in pre-tax profit by $5 \%$.

\section{Break-even point analysis}

According to analysts, Jaguar Land Rover needs annual sales of one-hundred-thousand vehicles to reach the break-even point, due to high fixed costs (Table 3) [10]. For 2014 the calculations reach a similar value. Because the average price per vehicle just rises by 12.4 percent from $2013-2015$ and the fixed costs rise by $48.2 \%$, the break-even point gets significantly higher every year from 2013-2015.

\section{Operating leverage}

According to Forbes, automotive companies generally have a high operating leverage, therefore being sensitive to fluctuations in sales volumes (Table 4) [5]. The change of sales by $1 \%$ had an impact on the change of operating income of $57 \%$ in 2013. In 2014 due to a higher Degree of Operating Leverage (short: DOL) an incremental change of sales would result in a three times higher change in operating income, in this year the automotive manufacturer JLR was very sensitive to sales changes. A high DOL suggests a major part of the costs being fixed costs in that year, which needs that in 2014 JLR was supposed to sell more cars. In 2015 the DOL was 83\%, which means that a change of sales by $1 \%$ would result in a change in operating income by $0.83 \%$. In the years 2013 and 2015 there apparently was a higher part of variable costs, generating smaller profits on incremental sales, but requiring lower sales than in 2014.

\section{Budgeting Process Review}

\section{Traditional process}

According to Wyles, Jaguar runs six facilities for $\mathrm{R} \& \mathrm{D}$, manufacturing and assembly in the UK, serving over 200 markets.

\begin{tabular}{|c|c|c|c|}
\hline & $\mathbf{2 0 1 5}$ & $\mathbf{2 0 1 4}$ & $\mathbf{2 0 1 3}$ \\
\hline $\begin{array}{c}\text { Sales Volume in thousand } \\
\text { units }\end{array}$ & 462 & 434 & 375 \\
\hline Inc./Dec. In \% & $6 \%$ & $16 \%$ & \\
\hline Cost in mill. GBP & 20463 & 18342,5 & 14965 \\
\hline Inc./Dec. In \% & $12 \%$ & $23 \%$ & \\
\hline Profit (pre-tax) in mill. GBP & 2614 & 2501 & 1674 \\
\hline Inc./Dec. In \% & $5 \%$ & $49 \%$ & \\
\hline
\end{tabular}

Table 2: Relationship between sales volume, cost and profit

\begin{tabular}{|c|c|c|c|}
\hline & $\mathbf{2 0 1 5}$ & $\mathbf{2 0 1 4}$ & $\mathbf{2 0 1 3}$ \\
\hline Revenue in GBP & 21866000000 & 19386000000 & 15784000000 \\
\hline Sales Volume & 462000 & 434000 & 375000 \\
\hline Fixed cost in GBP & 5223500000 & 4580000000 & 3523500000 \\
\hline $\begin{array}{c}\text { Average Price of one } \\
\text { KR in GBP }\end{array}$ & 47329,00 & 44668,20 & 42090,67 \\
\hline Break Even Point & 110366 & 102534 & 83712 \\
\hline
\end{tabular}

Table 3: Break-even point analysis.

\begin{tabular}{|c|c|c|c|}
\hline $\begin{array}{c}\text { Change in Operating Income } \\
\text { in \% }\end{array}$ & $\mathbf{2 0 1 5}$ & $\mathbf{2 0 1 4}$ & $\mathbf{2 0 1 3}$ \\
\hline Change in Sales \% & $6 \%$ & $49 \%$ & $13 \%$ \\
\hline DOL & $83 \%$ & $16 \%$ & $23 \%$ \\
\hline
\end{tabular}

Table 4: Operation leverage. 
Jaguar is further setting up a Joint Venture in China and more facilities in various countries. Asked about JLR's success after the takeover through Tata, Ratan Tata replied: "I think the general change that I see in JLR now is that everybody has enthusiasm about what they are doing and has confidence and faith in the direction of the company. We are not the magicians, they are the magicians" (ibid).

In fact, the company's spirit was the major reasons for the roaring success after 2008.

Actually the traditional budgeting process for the divisions was like below mentioned until the implementation of a new, integrated approach in 2013 (ibid):

- Functional units had their individual processes

- There were many parallel decision-making forums and there was a lack of focus on the outcome

- Limited trust in information across functions

- No clear code of conduct and lack of clear guidance

- Different plan intervals, data structures (different Excel Spreadsheets, manually processed) and time horizons

- Reports were put together manually from multiply systems

- No rigorous performance measures and accountability regarding the numbers

- Executive support for certain individual projects, but no sight for an integrated approach (integrated business planning)

\section{New approach (Integrated Business Planning)}

Due to the limitation of the old approach for a rapidly growing company like JLR, they embarked on a ERP project in waves from 2009 on (ibid). ERP platform was implemented in 12 months.

In 2013 PWC was hired to implement an integrated business approach, having the following aims (ibid):

- Standardized key planning resources across functions

- Decision making forums are aligned, outcomes linked to the forums

- Mutual trust in information between functions

- Common goals are implemented and mutual incentive system was established

- Linked timings, data structures and horizons

\begin{tabular}{|c|c|c|c|c|c|}
\hline $\begin{array}{c}\text { Year / Performance } \\
\text { Indicator }\end{array}$ & $\mathbf{2 0 1 1}$ & $\mathbf{2 0 1 2}$ & $\mathbf{2 0 1 3}$ & $\mathbf{2 0 1 4}$ & $\mathbf{2 0 1 5}$ \\
\hline Financial & & & & & \\
\hline Sales (in thsd. vehicles) & 241 & 306 & 375 & 434 & 462 \\
\hline Earning Growth (EBT) & $7,63 \%$ & $32,65 \%$ & $13,18 \%$ & $49,40 \%$ & $4,52 \%$ \\
\hline $\begin{array}{c}\text { Return On Equity } \\
\text { Eearnings per Share } \\
\text { (Tata Motors Ltd.) in } \\
\text { GOP }\end{array}$ & $35,57 \%$ & $50,58 \%$ & $47,30 \%$ & $42,65 \%$ & $43,28 \%$ \\
\hline $\begin{array}{c}\text { Non financial } \\
\text { Market Share } \\
\text { Workhvide }\end{array}$ & $0,46 \%$ & $0,58 \%$ & $0,55 \%$ & $0,60 \%$ & $0,64 \%$ \\
\hline $\begin{array}{c}\text { Customer Satisfaction } \\
\text { out of 1.000 points (1.0. }\end{array}$ & 837 & 827 & 827 & 808 & 877 \\
\hline \begin{tabular}{c} 
Power) \\
\hline
\end{tabular} & & & & 1,07 & \\
\hline
\end{tabular}

Table 5: Firm performance analysis
- Integrated reporting and information measures

- Accounting for the numbers for the sake of rigorous performance measures

- Incentives and management action for integrated approaches

Due to the integrated ERP approach, budgets and strategic goals had been aligned, especially creating the chance to individually, as well as collectively measure the company's/ divisions performance.

\section{Firms Performance Analysis}

\section{Financial}

Sales: In the five years from 2011-2015 there was a clear upward trend for the car sales. Car sales surged by two-hundred-twenty-onethousand vehicles or $91.70 \%$. In the four years from 2011-2014 one can see an annual sales growth by approximately seventy-thousand cars. From 2014 -2015 the sales growth rapidly slowed down to approximately thirty-thousand cars. This is mainly due to stagnating car sales in China (Table 5).

Earnings growth (EBT): From 2011 to 2012 the Earning Growth (EBT) increased from $7.63 \%$ to $32.65 \%$. In Earning Growth massively slowed by almost $20 \%$ to $13.18 \%$, to rise up to $49.40 \%$ (2014). In 2015 Earnings Growth cut back massively to $4.52 \%$. This could be explained with high investments in technology and R \& D.

Return on equity: In the years from $2011-2015$ one can observe constantly sinking ROE. This trend is contrary to increasing sales volumes. Normally one would expect rising ROE due to scale effects. As Jaguar Land Rover has largely expanded its investments in R \& D and high quality cars this trend is understandable. From $73.57 \%$ ROE in 2011 in 2015 the ROE decreased by approximately $32 \%$ to end up with $43.28 \%$.

Earnings per share: Earnings per Share for Jaguar Land Rover cannot be taken separately as JLR is a $100 \%$ daughter of Tata Motors Ltd. (Bajaj, 2012). As Ursa [7] states, JLR (100\% owned by Tata Motors Ltd.) approximately accounts for $90 \%$ of Tata Motor's shares value [7]. Therefore, here the EPS for Tata Motors is regarded, assuming that Tata's EPS equals JLR's EPS. From 2011 - 2014 there was a constant decrease in EPS from originally 3.4 GBP per share (2011) to 1.07 GBP per share (2014). Along with the appointment of new German CEO Ralf Spaeth, R \& D investments and generally re-investments of profits for the sake of sales growth had been decided. So the numbers correlate with what one knows about the firm's strategy. In 2015 EPS slightly rose to $1.22 \mathrm{GBP}$ per share.

\section{Non financial}

Market share worldwide: In the five years from 2011 - 2015 JLR accomplished to boost global market share by $0.18 \%$ from $0.46 \%$ in 2011 to $0.64 \%$ in 2015 . Only in 2013 the market share sank compared to the previous year $(-0.03 \%)$.

Customer satisfaction: According to American J. D. powers ranking JLR drivers' customer satisfaction is very high (above 800 points out of 1.000 points). From 2011 (833 points) at first in 2012 and 2013 customer satisfaction decreased by 6 points ( 827 points in 2012 and 2013). Again in 2014 customer satisfaction decreased by 19 points, still having a high value of 808 points. In 2015 eventually JLR achieved to create a jump in customer satisfaction, presumably because of the new models, up to 877 points. It seems that the high investments in $\mathrm{R}$ \& D and the new models eventually paid off in 2015. 


\section{Capital Investment Analysis}

\section{Capital expenditures}

According to Jaguar Land Rover for 2014 the long term capital spending target is $10-12 \%$ of the revenue in line with the premium market competitors [11]. In the financial year 2014 Jaguar invested 2.5 bn. GBP in capital (ibid). Approximately half of the capital investments were made for R \& D Investments (45\%) and the other half were made for tangibles fixed assets (55\%), such as equipment, tools and a joint venture in China (ibid).

Investments were carried out to substantially develop new products in prospective as well as existing markets. Exploring new powertrains and technological advancements was made in order to meet customers and regulatory expectations. Also capital investments were so high due to increasing demand for JLR cars in the UK and abroad. JLR is convinced that the high capital investments are effectively contributing to high growth for the company in near and far future (ibid).

Growth in sales and increased profitability along with a strong cash and liquidity stance supported the aforementioned strategy. In 2014 free cash and investment and interest were robust and stronger than expected, supporting the capital investment strategy (ibid).

For 2015 JLR increased its capital expenditure and R \& D investment in by $14.43 \%$ [12]. CAPEX and R \& D meanwhile rose to 3.147 bn. GBP [12]. This comes along with the plans expand production capacities in the UK, China and Brazil [11]. R \& D sank in 2015 by $5 \%$ to $40 \%$ and CAPEX rose by $5 \%$ to reach $60 \%$ (ibid). Still the free cash flow remained to be positive due to increased sales, higher than expected [1].

\section{Capital projects}

According to Grandhi there is a secret plan of Jaguar Land Rover to cut $£ 4.5$ bn of company costs and to sell 1 million cars per year until 2020. This should be realized by cutting jobs to save cash, similarly measures will be taken to slow or stop hiring for new positions [13]. Additionally, supply chains will be reviewed for better efficiency and the companies wants to share core skeletons for Jaguars and Land Rovers to spare money (ibid).

Another current project of JLR is to create loop-value-chain.

\section{Competitive Analysis}

\section{Three key competitors}

Observing the US market for luxury cars gives a good picture of the main competitors of JLR in the premium segment (Figure 6). The three main competitors for JLR in the U.S are Mercedes Benz (GER), Lexus (JPN) and Audi (GER). As JLR held a market share of around $5 \%$ of the U.S car market, it was far off from Audi (9.6\%), Lexus (16.4\%) and Mercedes-Benz (17.7\%).

\section{Comparison of the basis for competition}

Cost: Comparing the two main competitors on the American market, Mercedes-Benz and Lexus (no separate financial information for Lexus, included in the financial statement of Toyota), one can see, that the average selling prices of approximately 47.000 GBP for Mercedes-Benz and Jaguar are nearly similar. As there is no data for Lexus, the values for Toyota have been taken. Toyota's average selling price in GBP is significantly lower with $23.703,78 \mathrm{GBP}$, being almost $50 \%$ below the selling prices of Jaguar and Mercedes-Benz. As the selling price of Mercedes-Benz is in average $0.3 \%$ below the selling price of JLR and the cost of production in average is $1.91 \%$ higher for
Mercedes-Benz than for JLR, the comparative cost advantage of JLR to Mercedes-Benz is $2 \%$. The cost advantage of JLR to Toyota is $1.31 \%$. In the cost ranking of the three brands observed, Jaguar takes the best rank, Toyota the second and Mercedes-Benz the third rank (Table 6).

Capital intensity: Comparing the invested capital in GBP in 2015 to the three competitors' revenues in 2015 it is noticeable, that as Mercedes-Benz only re-invested 3\% of its revenue, Toyota already invested $8 \%$ of its revenue. Jaguar Land Rover invested $17 \%$ of the revenue in the company. It may be assumed, that a large part of the JLR's current success is due to the high capital investment (Table 7).

Branding: According to Bhasin Jaguar Land Rover is synonymous with smooth, fast and luxurious vehicles. Jaguar has no low cost cars, like BMW or Mercedes-Benz. Jaguar is further preferred by people spending a lot of time in their vehicles (ibid). In the 1940s and 50s Jaguar created sports vehicles which caught the eye. Still Jaguar is seen as a symbiosis of supportiveness and luxury. Moreover, their cars became an integral part of the motor sport industry for decades. Hence, it can be said that Jaguar Land Rover is only located in the premium segment.

Mercedes-Benz is also located in the premium segment, according to Stephen Zoeller [14]. Through market segmentation, Mercedes-Benz accomplishes to maintain its premium image while gaining younger customers. Smaller and "younger" models (CLA) are introduced, which do not compete with the high-class premium models like S-class.

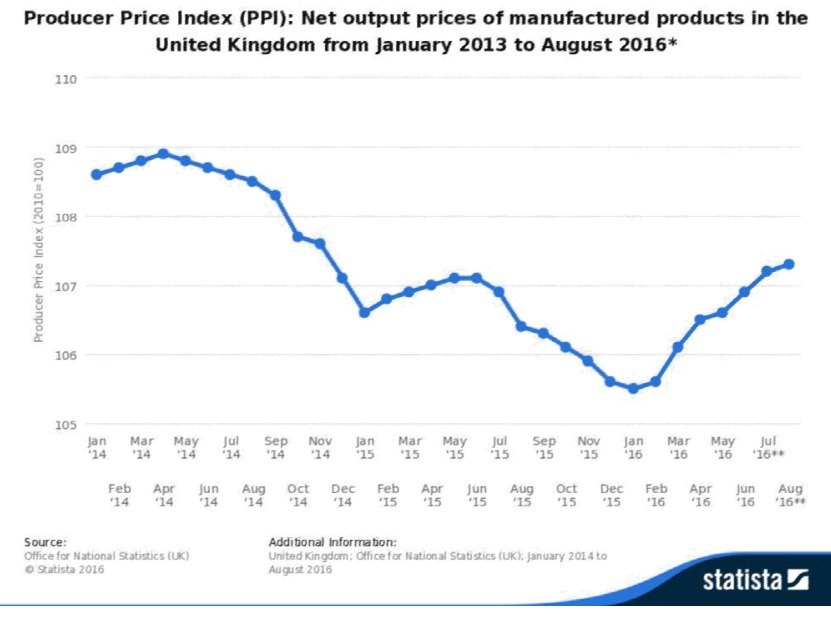

Figure 6: Competitive analysis.

\begin{tabular}{|c|c|c|c|}
\hline Brand & $\begin{array}{c}\text { Cost of production } \\
\text { per car in 2015 in } \\
\text { GBP }\end{array}$ & $\begin{array}{c}\text { Average selling } \\
\text { prices in GBP }\end{array}$ & $\begin{array}{c}\text { Cost percentage } \\
\text { of selling price }\end{array}$ \\
\hline Mercedes-Benz & 42813,94 & 47168,86 & 0,907673834 \\
\hline Lexus (Toyota) & 21362,24 & 23703,78 & 0.901216599 \\
\hline $\begin{array}{c}\text { Jaguar Land } \\
\text { Rover }\end{array}$ & 42012,87 & 47307,6 & 0.88807866 \\
\hline
\end{tabular}

Table 6: Comparison on the basis for competition.

\begin{tabular}{|c|c|c|c|}
\hline Brand & $\begin{array}{c}\text { Revenue In GBP } \\
\text { in 2015 }\end{array}$ & $\begin{array}{c}\text { Invested Capital } \\
\text { in GBP in 2015 }\end{array}$ & $\begin{array}{c}\text { Capital Invested } \\
\text { / Revenue }\end{array}$ \\
\hline Mercedes-Benz & $1,495 \mathrm{E}+11$ & 4591000000 & $3 \%$ \\
\hline Lexus (Toyota)* & $2,126671.11$ & 17121000000 & $8 \%$ \\
\hline Jaguar Land Rover & 22200000000 & 3700000000 & $17 \%$ \\
\hline
\end{tabular}

Table 7: Capital intensity. 
In the Lexus brand guideline, it is stated: "Great brands live in people's hearts and minds we stand for more than premium luxury automobiles" [15].

The four key words of the company's brand guideline are (ibid):

1) Essence

2) Promise

3) Benefits

4) Personality

One can notice that all of the three regarded brands are aiming at a premium segment, offering unique and high class cars with a great degree of personalization.

\section{Comparison of performance metrics}

Revenue growth: Concerning revenue growth, it can be said, that from the four observed car manufacturers Jaguar had the second largest revenue growth with $12.90 \%$ in 2015 right behind MercedesBenz (15.09\%) (Table 8).

EBIT: Regarding EBIT, Jaguar took the third place (8\%) competing with the direct competitors behind Mercedes-Benz (13.20\%) and Lexus $\left({ }^{*}\right.$ due to no separate financial statement for Lexus Toyotas is regarded) (9\%). Audi took the last place with 5.3\% in 2015 .

Return on equity: As Jaguar's shares are $100 \%$ owned by Tata Motors Ltd. No separate ROE is calculated; instead the ROE of Tata Motors (JLR accounts for $90 \%$ of Tata Motors value) is taken. Here Tata Motors Ltd. has the highest ROE in 2015 with $24.86 \%$, followed by Audi (21\%), Mercedes-Benz (17.33\%) and Toyota (incl. Lexus) $14.20 \%$.

Financial leverage multiplier: Concerning the Financial Leverage Multiplier, a low value is favorable. JLR has the lowest FLM with 1.51, followed by Toyota (incl. Lexus) (2.84), Audi (2.67), and MercedesBenz (4.05). Financially JLR is very well off, leaving potential for expansion.

Receivables turnover: Tata Motors Ltd. (including JLR) has the highest Receivables Turnover, which means the highest credit sales value compared to the accounts receivable. A lower value is favorable due to security reasons. Mercedes-Benz has the second worst value (16.90\%), Audi the second best (15.09\%) and Lexus the best value (13.14\%) in 2015.

Payables period: Tata Motors Ltd. (incl. JLR) has by far the highest Payables Period with 126.93 days, more than four times the lowest value (Mercedes-Benz) with 32.14 days. Audi takes the second place with a Payables Period of 50.54 days. The third place Toyota (incl. Lexus) takes with 38.63 days.

\begin{tabular}{|c|c|c|c|c|}
\hline Brand / Performance Metric & Jaguar & $\begin{array}{c}\text { Mercedes } \\
\text { Benz }\end{array}$ & Lexus • & Audi \\
\hline Revenue growth & $12,90 \%$ & $15,09 \%$ & $8,10 \%$ & $8,61 \%$ \\
\hline EBIT & $8,00 \%$ & $13,20 \%$ & $9,00 \%$ & $5,30 \%$ \\
\hline Return On Equity & 24,8690 & $17,33 \%$ & $14,20 \%$ & $21,00 \%$ \\
\hline $\begin{array}{c}\text { Financial Leverage } \\
\text { Multiplier }\end{array}$ & 1,51 & 4,05 & 2,84 & 2,67 \\
\hline Receivables Turnover & $21,82 \%^{\prime}$ & $16,90 \%$ & $13,14 \%$ & $15,09 \%$ \\
\hline Payables Period & 126,93 & 32,14 & 38,63 & 50,54 \\
\hline Asset Turnover & $87,00 \%{ }^{*}$ & $73,00 \%$ & $61,00 \%$ & $109,00 \%$ \\
\hline Market Share & $0,64 \%$ & $2,59 \%$ & $0,90 \%$ & $2,49 \%$ \\
\hline Market Share Growth & $6,70 \%$ & $-13,40 \%$ & $12 \%$ & $3,60 \%$ \\
\hline
\end{tabular}

Table 8: Performance metrics comparison.
Asset turnover: Looking at the AT, Tata Motors Ltd. (incl. Jaguar Land Rover) takes the second place (87\%) behind Audi (109\%). Mercedes-Benz takes the third place with $73 \%$ and Toyota (incl. Lexus) the last place with $61 \%$.

Market share: Measuring the market share Mercedes-Benz takes the first place with a world-wide market share of $2.59 \%$, Audi the second place with $2.49 \%$, Lexus the third place with a market share of $0.90 \%$ and JLR the last place with a market share of $0.64 \%$. Therefore, JLR is the smallest of the observed competitors in this sample.

Market share growth: Mercedes-Benz had the highest market share growth in 2015 with $13.40 \%$, Lexus had a market share growth in 2015 of $12 \%$. JLR took the third place with an increase of global market share by $6.7 \%$. The last place took Audi with a global market share growth of $3.6 \%$ in 2015 .

\section{Balance Scorecard Sketch}

Balance Scorecard Sketch shown in Figure 7.

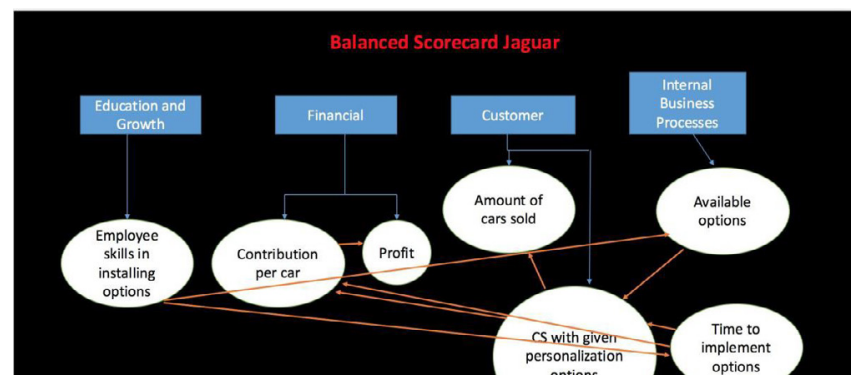

Figure 7: Balance scorecard sketch.

\section{Conclusion}

Starting with a rough stance of Jaguar Land Rover in 2008, when it was taken over through Tata Motors Ltd. today one can claim, that JLR is one of the most profitable car manufacturers in the world, offering a bunch of new products and innovation. Through the takeover Jaguar Land Rover has not lost its shimmering lustre of the past, even more it gained prestige in the last years under the regency of Tata, along with German CEO Ralph Spaeth. Cost analysis shows overall increasing cost, which goes along with massive investments and results in the growth process and significantly rising sales. The budgeting process has been changed for the good through an integrated approach with the help of PWC, the firm's performance analysis shows excellent results. Capital investments are high and resulting in the aspired enormous growth, on the other side JLR accomplishes to regularly create positive free cash flows, even with the massive capital spending. The capital project 2020 is ambitious, but manageable, regarding JLR's huge success implementing new strategies. Compared with the competition in the premium segment JLR is very well off, selling more and more cars and generating huge revenues. Still the company lives up to the responsibility to be a good employer and invests enormous amounts in $\mathrm{R} \& \mathrm{D}$, as well as facilities. I can just conclude that Jaguar became one of the most profitable and fastest growing premium carmaker in the world, creating excellent cars with a high prestige, perpetually supporting innovation and social responsibility. All indicators suggest that there could have not been a better opportunity for Jaguar Land Rover than being taken over by Tata Motors in 2008 . 
Citation: Fiedler FFH-J (2018) Jaguar Landover: A Traditional English Car Manufacturer in Indian Hands - A Good Deal? An Evaluation. J Account Mark 7: 292. doi: 10.4172/2168-9601.1000292

Page 7 of 7

\section{References}

1. Jaguar L Rover (2016) Jaguar Land Rover Reports Full-Year Results For Fiscal 2015/16.

2. Schmidt B (2016) Fahrbericht Jaguar F-Pace Auf den Spuren des Cayenne. Frankfurter Allgemeine Zeitung, 22th August.

3. Jaguar Land Rover (2016) About Us.

4. Jing Daily 2014.

5. Trefis Team (2015) Tata: Jaguar Land Rover Stepping Up Investment To Boost Sales.

6. Jaguar Land Rover (2015) Jaguar Land Rover Monthly Retail.

7. Ursa V (2014) Jaguar Land Rover: Right Time for A London IPO?

8. Yahoo Finance (2016) Tata Motors Limited (TTM) Add to watchlist NYSE NYSE Real Time Price. Currency in USD.
9. Kallstrom $H$ (2015) Raw materials - the biggest cost driver in the auto industry.

10. Talgeri $K N$ (2008) In the final analysis, even though JLR will be fully owned by Tata Motors, the two companies have to function as independent businesses.

11. Jaguar Land Rover (2015) Jaguar Land Rover Reports Full-Year Results For Fiscal 2014/15.

12. Jaguar Land Rover (2015) Annual Report 2014-15.

13. Nofuente K (2015) Jaguar Land Rover Has Secret Plan To Reduce Costs By \$6.8 Billion, Build 1 Million Cars Per Year. Tech Times, 11th November.

14. Zoeller S (2016) How Mercedes-Benz uses market segmentation.

15. Lexus (2012) Lexus Brand Guideline. 